\title{
PROBLEMATIKA DALAM PELESTARIAN TRADISI ANGKLUNG BADUD DI DESA MARGAJAYA KECAMATAN CIJULANG
}

\author{
Krisna Sujaya ${ }^{1}$ \\ Dosen Universitas Siliwangi \\ Jl. Siliwangi No. 24 Kota Tasikmalaya 46115 Jawa Barat
}

\begin{abstract}
ABSTRAK
Tradisi angklung badud merupakan salah satu bentuk kesenian berjenis angklung buhun yang berasal dari Dusun Margajaya Kecamatan Cijulang Kabupaten Pangandaran. Tradisi angklung badud tumbuh dan berkembang dalam masyarakat Dusun Margajaya, Kecamatan Cijulang. Hal ini diindikasikan dari penggunaan tradisi angklung badud sebagai media dalam ritual pertanian padi, yang merupakan mayoritas profesi masyarakat Dusun Margajaya, Kecamatan Cijulang. Penelitian ini termasuk dalam penelitian deskriptif kualitatif, yaitu penelitian yang memberikan gambaran mengenai keadaan atau gejala yang terjadi tanpa melepaskan objek yang diteliti. Teknik pengumpulan data dalam penelitian ini menggunakan teknik observasi, wawancara dan dokumentasi. Hasil penelitian ini bahwa seiring dengan berkembangnya zaman dan kemajuan teknologi yang semakin maju, perkembangan dan pelestarian tradisi angklung badud semakin memprihatinkan. Banyak faktor yang yang menjadikan eksistensi tradisi angklung badud berada di posisi yang mengkhawatirkan. Beberapa faktor yang mempengaruhi terhambatnya perkembangan angklung badud diantaranya: 1). Perubahan sistem pertanian masyarakat sebagai akar tradisi angklung badud, 2). Sistem pewarisan yang kurang optimal, 3). Akulturasi budaya yang menggerus pelestarian angklung badud. 4). Mind set masyarakat yang lebih menyukai hal-hal yang bersifat modern, 5). Kurangnya kesadaran masyarakat dalam melestarikan tradisi lokal, 6). Kepedulian pemerintah daerah yang kurang optimal terhadap pelestarian angklung badud.
\end{abstract}

\section{Kata Kunci: Tradisi Angklung Badud dan Angklung Badud}

\begin{abstract}
The tradition of Badud angklung is one of the art forms of angklung buhun originating from Margajaya Hamlet, Cijulang District, Pangandaran Regency. The Badud angklung tradition grows and develops in the people of Margajaya Hamlet, Cijulang District. This is indicated by the use of the angklung badud tradition as a medium in rice farming rituals, which constitutes the majority of the profession of the people of the Margajaya Hamlet, Cijulang District. This research is included in descriptive qualitative research, namely research that provides an overview of the situation or symptoms that occur without releasing the object under study. Data collection techniques in this study used observation, interview and documentation techniques. The results of this study that along with the development of the times and increasingly advanced technological advances, the development and preservation of the Badud angklung tradition is increasingly alarming. Many factors that make the existence of the Angud Angklung tradition in a worrying position. Several factors that influence the development of badud angklung include: 1). Changes in the community farming system as the root of the Badud angklung tradition, 2). Less optimal inheritance system, 3). Cultural acculturation which undermines the preservation of badud angklung. 4). The mind set of people who prefer things that are modern, 5). Lack of public awareness in preserving local traditions, 6). The sub-optimal government's concern for the preservation of badud angklung.
\end{abstract}

Keywords: Angklung Badud Tradition and Angklung Badud

\footnotetext{
${ }^{1}$ Penulis Koresponden

E-mail address: jurnalartefaksejarah@gmail.com doi: http://dx.doi.org/10.25157/ja.v5i1.1912
} 


\section{PENDAHULUAN}

Indonesia merupakan negara yang memiliki tingkat keanekaragaman yang sangat luar biasa tinggi. Perbedaan yang paling kentara terlihat dalam perbedaan tersebut diantaranya adat, budaya, bahasa dll. Warisan budaya yang luar biasa di Indonesia merupakan modal yang sangat besar dalam mengembangkan pendapatan daerah dan negara dari sektor pariwisata.

Salah satu produk budaya yang berkembang di Dusun Margajaya, Kecamatan Cijulang adalah tradisi angklung badud. tradisi angklung badud merupakan hasil berbentuk produk dari kebudayaan yang terbuat dari bambu dan biasa disebut secara luas menjadi kesenian angklung. Produk hasil dari kebudayaanyang terbuat dari bambu di Jawa Barat, khususnya di Kabupaten Pangandaran tidak lepas dari kultur sosial masyarakat Kabupaten Pangandaran sendiri yang mayoritas sebagai petani serta melimpahnya bahan baku pembuatan angklung yaitu bambu. fenomena tersebut senada dengan apa yang disampaikan oleh Budi (2001: 3) yang menyatakan bahwa angklung berkembang di masyarakat Jawa Barat (Sunda) yang berbudaya agraris tradisional, orang Sunda menamakanya dengan "ngahuma". Dilihat dari fungsinya angklung dalam masyarakat sunda selalu dikaitkan dengan upacara ritual yang ditujukan kepada Dewi Sri, yang dipercaya oleh masyarakat sunda sebagai dewi kesuburan. Ketika di analisis urgensi dalam tradisi angklung badud memiliki nilai-nilai luhur yang diajarkan oleh para leluhur orang sunda secara turun temurun yaitu:

1. Nilai gotong royong;

2. Nilai kebersamaan

3. Nilai Persaudaraan

Tradisi angklung badud merupakan salah satu bentuk kesenian berjenis angklung buhun yang berasal dari Dusun Margajaya Kecamatan Cijulang Kabupaten Pangandaran. tradisi angklung badud berdasarkan prespektif historis digunakan sebagai sarana untuk ritual yang berhubungan dengan profesi masyarakat sekitar yang mayoritas berprofesi sebagai petani padi, ritual tersebut merupakan ungkapan rasa syukur masyarakat petani terhadap keberhasilan panen padi yang ditujukan kepada Dewi Sri (Masunah, 2003: 42). Tradisi angklung badud tumbuh dan berkembang dalam masyarakat Dusun Margajaya, Kecamatan Cijulang. Hal ini diindikasikan dari penggunaan tradisi angklung badud sebagai media dalam ritual pertanian padi, yang merupakan mayoritas profesi masyarakat Dusun Margajaya, Kecamatan Cijulang.

Seiring dengan berkembangnya zaman dan kemajuan teknologi yang semakin maju, perkembangan dan pelestarian tradisi angklung badud semakin memprihatinkan. Banyak faktor yang yang menjadikan eksistensi tradisi angklung badud berada di posisi yang mengkhawatirkan. Beberapa faktor yang mempengaruhi terhambatnya perkembangan angklung badud diantaranya:

1. Perubahan sistem pertanian masyarakat sebagai akar tradisi angklung badud

2. Sistem pewarisan yang kurang optimal.

3. Akulturasi budaya yang menggerus pelestarian angklung badud

4. Mind set masyarakat yang lebih menyukai hal-hal yang bersifat modern

5. Kurangnya kesadaran masyarakat dalam melestarikan tradisi lokal

6. Kepedulian pemerintah daerah yang kurang optimal terhadap pelestarian angklung badud

Perubahan kultur sosial masyarakat

Dusun Margajaya, Kecamatan Cijulang dan perubahan pola pertanian padi yang asalnya sistem huma menjadi sistem persawahan, mengakibatkan tradisi angklung badud sudah hampir tidak dilaksanakan secara kontinyu. Oleh sebab itu secara otomatis tradisi angklung badud juga kehilangan fungsi-fungsi dasar dan awalnya sebagai sarana ritual dalam masyarakat yang kemudian digantikan dengan fungsi hiburan semata. Hal tersebut mengakibatkan budaya yang tumbuh dan berkembang di dalam masyarakat Dusun Margajaya, Kecamatan Cijulang mengalami regresi dan lebih cenderung tergantikan oleh budaya modern.

Tradisi angklung badud yang pada kenyataannya mengalami perubahan fungsi dan makna dari ritual menjadi hiburan, hal tersebut menuntut para pemerhati tradisi angklung badud untuk terus ber inovasi secara efektif sehingga tradisi angklung badud dapat bertahan dan berkembang di tengah arus modernisasi yang tidak bisa di elakan lagi. Kondisi sosial kemasyarakatan Kecamatan Cijulang yang bergeser pada budaya yang bersifat modern, semakin tidak menguntungkan pada eksistensi tradisi angklung badud sekarang ini. Kondisi sosial yang menghinggapi para pewaris tradisi angklung badud yang membuat mereka beralih profesi kepada profesi yang menjamin secara 
finansial. Inovasi untuk tetap melestarikan angklung badud pada dasarnya kurang begitu optimal. Hal demikian terjadi karena kemajuan arus modernisasi yang semakin lama semakin kuat dan menjamur. Sementara perhatian pemerintah daerah terhadap tradisi angklung badud juga belum maksimal, hal ini yang mempercepat regresi perkembangan tradisi angklung badud. Regresi tradisi lokal sebagai aset budaya daerah dapat terjadi, apabila lingkungan pendukung masyarakat apalagi generasi muda tidak memiliki kesadaran dan kepedulian serta tidak memilki inisiatif untuk melestarikan tradisi budaya lokal tersebut.

\section{METODE PENELITIAN}

\section{Pendekatan Penelitian}

Penelitian ini termasuk dalam penelitian deskriptif kualitatif, yaitu penelitian yang memberikan gambaran mengenai keadaan atau gejala yang terjadi tanpa melepaskan objek yang diteliti. Menurut Bogdan dan Tylor dalam Moloeng (2013: 4) penelitian kualitatif adalah penelitian yang menghasilkan data deskriptif berupa kata-kata tertulis atau lisan dari orangorang dan perilaku yang diamati.

\section{Objek Penelitian}

Menurut Ratna (2010: 135), ruang lingkup objek penelitian dibedakan menjadi tiga yaitu (1) benda (artifact), (2) hubungan-hubungan sosial (socifact), (3) pikiran dan perasaan (mentifact)

\section{Teknik Pengumpulan Data}

Creswell (2012: 267-270) menyatakan bahwa prosedur pengumpulan data dalam penelitian kualitatif melibatkan empat jenis strategi yaitu observasi kualitatif, wawancara kualitatif, studi dokumen (dokumen-dokumen kualitatif, materi audio, visual dan audio visual) dan studi pustaka. Teknik pengumpulan data dalam penelitian ini adalah observasi lapangan, wawancara, dokumentasi.

Creswell (2012: 267) menyatakan bahwa observasi merupakan aktifitas yang di dalamnya peneliti langsung turun ke lapangan untuk mengamati perilaku dan aktivitas individuindividu di lokasi penelitian. Menurut Esterberg dalam Satori dan Komariah (2013: 130) wawancara adalah merupakan pertemuan dua orang untuk bertukar informasi dan ide melalui tanya jawab, sehingga dapat dikonstruksikan makna dalam suatu topik tertentu. Dokumentasi adalah teknik yang berhubungan dengan sumber data, dokumentasi berkaitan dengan sumber terkhir, interaksi bermakna antara individu dengan individu, individu dengan kelompok, interaksi internal dalam diri sendiri, seperti hasilhasil karya baik ilmiah maupun non ilmiah, catatan karya seni dan bentuk catatan harian lainnya (Ratna, 2010: 234).

\section{HASIL PENELITIAN DAN PEMBAHASAN}

Di era serba modern seperti sekarang ini, pengembangan dan pelestarian budaya lokal memiliki tantangan yang lebih berat. Modernisasi sendiri pada dasarnya memiliki efek negatif dan positif, akan tetapi khusus bagi pengembangan tradisi angklung badud modernisasi justru memiliki efek yang negatif.

Lemahnya pelestarian tradisi angklung badud seyogyanya telah dikhawatirkan oleh para tokoh setempat yang bergelut di seni tradisi angklung badud. Hal tersebut dapat tercermin dari jarang sekali pada saat ini pertunjukan tradisi angklung badud. Beberapa urgensi dari problematika pelestarian tradisi angklung badud yang ditemui di dusun Margajaya, Kecamatan Cijulang diantaranya:

1. Perubahan sistem pertanian masyarakat sebagai akar tradisi angklung badud

Perubahan pola kehidupan pertanian masyarakat Cijulang khususnya di masyarakat petani dusun Margajaya yang disebabkan kuatnya arus modernisasi yang mengakibatkan tradisi angklung badud semakin jarang dipentaskan. Hal itu diakibatkan berubahnya struktur atau cara bertani, terutama dalam melaksanakan panen. Dahulu setelah panen, masyarakat dusun Margajaya selalu mengadakan ritual mamarung dengan menampilkan tradisi angklung badud sebagai bentuk rasa syukuratas keberhasilan dalam melaksanakan panen, akan tetapi setelah berubahnya pola panen masyarakat menjadi lebih modern, maka upacara mamarung yang merupakan ritual utama dalam diselenggaranya tradisi angklung badud sudah tidak diselenggarakan lagi dan itu secara otomatis tradisi angklung badud juga tidak di selenggarakan.

2. Sistem pewarisan yang kurang optimal.

Sistem pewarisan yang di implementasikan dalam pelestarian tradisi angklung badud di Dusun Margajaya, 
Kecamatan Cijulang pada dasarnya belum optimal, hal ini dikarenakan sistem pewarisan tradisi angklung badud hanya bersifat informal. Pewarisan dengan sistem informal di era modern sekarang ini jelas kurang efektif, hal ini dikarenakan dalam pelestarian tradisi angklung badud hanya bersifat menunggu kesadaran dari generasi selanjutnya, tanpa ada pewarisan secara formal dengan cara menginternalisasikan tradisi angklung badud ke dalam program-program, baik pendidikan ataupun program pemerintah daerah, sehingga ada kewajiban bagi para generasi penerus untuk senantiasa dapat menjaga dan melestarikan tradisi angklung badud.

\section{Akulturasi budaya yang menggerus} pelestarian angklung badud

Masuknya tradisi budaya masyarakat lain akan sangat mempengaruhi keberlangsungan sebuah produk tradisi budaya masyarakat lokal. Akulturasi budaya dapat terjadi apabila 2 (dua) kelompok masyarakat dengan latar belakang kebudayaan yang berbeda hidup bersama dan terus berinteraksi secara kontinyu dalam kurun waktu yang lama. Besar kemungkinan bahwa salah satu budaya atau mungkin keduanya dapat berubah kebudayaannya karena pengaruh kebudayaan lain tersebut. Akulturasi pada dasarnya akan sangat berpengaruh terhadap munculnya produk trdisi budaya baru akibat percampuran budaya atau yang lebih mengkhawatirkan yaitu hilangnya tradisi budaya lokal dan tergantikan oleh tradisi budaya baru yang secara filosofis belum tentu cocok apabila di implementasikan didalam kehidupan seharihari masyarakat.

Pola kehidupan masyarakat dusun margajaya, Kecamatan Cijulang saat ini sudah akrab dengan teknologi yang semakin tidak terbendung. Hal tersebut memberikan kesempatan yang seluas-luasnya bagi masyarakat setempat untuk dapat mengetahui tradisi di luar daerahnya, bahkan luar negaranya sehingga tradisi budaya lokal dapat tersisihkan.

Secara administratif dusun Margajaya, Kecamatan Cijulang termasuk ke dalam wilayah administratif Kabupaten Pangandaran yang menjadi daerah pariwisata unggulan Provinsi Jawa Barat yang sudah barang tentu menjadi tujuan wisatawan lokal, luar daerah bahkan luar negeri untuk berlibur, hal tersebut jelas akan mengakibatkan akulturasi budaya di dalam masyarakat yang akan berdampak pada pelestarian tradisi budaya lokal, khususnya tradisi angklung badud.
4. Mind set masyarakat yang lebih menyukai hal-hal yang bersifat modern

Fakta yang tidak bisa terbantahkan tradisi angklung badud sudah mulai di tinggalkan oleh masyarakat lokal. Selain kalah bersaing dengan tradisi modern, masyarakat yang sudah terbiasa berdampingan dengan kegiatan tradisi modern secara psikologis akan lebih mudah untuk ter doktrin dengan berbagai hal yang bersifat modern, salah satunya tradisi modern yang dengan sendirinya terinternalisasikan kedalam kehidupan masyarakat. Masyarakat yang sudah terpapar arus modernisasi menganggap tradisi modern lebih baik dan menarik dibandingkan dengan tradisi angklung badud yang pada dasarnya merupakan sebuah produk budaya setempat yang diwariskan turun temurun kepada masyarakat.

Kekhawatiran akan macetnya regenerasi pelestari angklung badud sudah semakin nyata, hal tersebut dapat di analisis dari minat dan mind set generasi muda setempat yang berangsurangsur meninggalkan tradisi angklung badud dan mengalihkan kepedulian mereka kepada halhal yang bersifat materialis dan modernis.

\section{Kurangnya kesadaran masyarakat dalam} melestarikan tradisi lokal

Masyarakat merupakan sebuah unsur terpenting dalam upaya pelestarian tradisi angklung badud di dusun Margajara, Kecamatan Cijulang. Tradisi tersebut hidup dan berkembang sejak jaman dulu dan terintegrasi dengan nilainilai kehidupan masyarakat setempat. Seiring dengan perkembangan zaman yang semakin maju dan modern menghasilkan individuindividu yang individualistis di dalam masyarakat. Sifat individualistis itu sendiri menjadi salah satu problematika yang harus di hadapi dalam upaya pelestarian berbagai jenis tradisi budaya.

Eksistensi tradisi angklung badud di dusun Margajaya, Kecamatan Cijulang sangat bergantung pada tingkat kesadaran dan kepedulian masyarakat setempat yang seharusnya senantiasa menjaga tradisi lokal sebagai ciri atau identitas masyarakat setempat. Pergeseran kesadaran masyarakat terhadap upaya menjaga dan melestarikan tradisi angklung badud dipengaruhi oleh sifat individualistis tadi dan mengesampingkan rasa kebersamaan di dalam masyarakat, sehingga secara tidak langsung akan berdampak pada eksistensi tradisi angklung badud yang semakin 
tidak diminati oleh masyarakat lokalnya itu sendiri.

6. Kepedulian pemerintah daerah yang kurang optimal terhadap pelestarian angklung badud

Keterancaman eksistensi tradisi angklung badud sendiri seolah tidak menjadi perhatian khusus pemerintah daerah. Pemerintah daerah yang pada dasarnya berkewajiban menjaga dan melestarikan tradisi angklung badud justru terkesan lamban dalam membuat solusi agar tradisi angklung badud dapat terus terjaga dan berkembang. Tidak adanya regulasi kebijakan mengenai pelestarian tradisi angklung badud menjadi salah satu faktor hampir hilangnya tradisi angklung badud di Dusun margajaya, Kecamatan Cijulang.

Pemerintah daerah setempat lebih cenderung tertarik pada pengembangan pariwisata alam berupa laut dll, di bandingkan dengan pariwisata budaya. Padahal pariwisata budaya, khususnya tradisi angklung badud yang termasuk kedalam produk kesenian buhun memiliki potensi yang sangat besar untuk dikembangkan dan dimanfaatkan sebagai daya tarik wisata. Banyak manfaat yang diperoleh oleh pemerintah daerah apabila mengembangkan tradisi angklung badud diantaranya:

a. Mengenalkan budaya lokal kepada masyarakat luas

b. Menarik wisatawan yang peduli terhadap pelestarian nilai tradisi budaya lokal

c. Terjaganya eksistensi tradisi angklung badud di wilayah pemerintah daerah setempat.

d. Menambah lapangan pekerjaan khususnya pekerja seni (tradisi angklung badud)

\section{PENUTUP}

\section{Simpulan}

Problematika yang mempengaruhi terhambatnya perkembangan angklung badud yaitu Perubahan sistem pertanian masyarakat sebagai akar tradisi angklung badud, Sistem pewarisan yang kurang optimal, Akulturasi budaya yang menggerus pelestarian angklung badud, Mind set masyarakat yang lebih menyukai hal-hal yang bersifat modern, Kurangnya kesadaran masyarakat dalam melestarikan tradisi lokal, Kepedulian pemerintah daerah yang kurang optimal terhadap pelestarian angklung badud

\section{Saran}

Saran yang dapat diambil diajukan dalam penelitian ini yaitu Peratama, dibutuhkan upaya dari berbagai steakholder yang terkait untuk senantiasa menjaga tradisi angklung badud. Kedua, semakin ditingkatkan kesadaran dan kepedulian masyarakat terhadap pelestarian tradisi lokal khususnya tradisi angklung badud. Ketiga, Optimalisasi peran pemerintah daerah dalam pelestarian tradisi angklung badud.

\section{DAFTAR PUSTAKA}

Budi, Dinda Satya Upaja. 2001. Angklung Baduy dalam Upacara Ritual Ngaseukeun. Program Pasca Sarjana seni Pertunjukan. Jurusan Ilmu-Ilmu Humaniora. Universitas Gajah Mada. tidak di Publikasikan

Creswell, John W. 2012. Research Design. Yogyakarta. Pustaka Pelajar.

Kubarsah, R. Ubun. 1994. Waditra Mengenal Alat-Alat Kesenian Daerah Jawa Barat. Bandung: CV. Sampurna.

Masunah, Juju. 2003. Angklung di Jawa Barat. Bandung: P4ST UPI.

Moleong, J.L. 2013. Metodologi Penelitian Kualitatif (Cetakan ke-31). Bandung: PT. Remaja Rosdakarya.

Peursen, van. 1988. Strategi Kebudayaan. Edisi Kedua. Yogyakarta: Penerbit Kanisius

Ranjabar, Jacobus. 2006. Sistem Sosial Budaya Indonesia Suatu Pengantar, Bandung, Ghalia.

Ratna, I Nyoman Kutha. 2010. Metode Penelitian; Kajian Budaya dan Ilmu Sosial Humaniora Pada Umumnya. Yogyakarta. Pustaka Pelajar.

Satori, Djam'an dan Komariah, Aan. 2013.Metode Penelitian Kualitatif. Bandung.PT. Remaja Rosdakarya.

Wiramihardja, Obby A.R 2010. Panduan Bermain Angklung. Jakarta. Pusat Penelitian dan Pengembangan Kebudayaan Badan Pengembangan Sumber Daya Kebudayaan dan Pariwisata Kementrian Kebudayaan dan Pariwisata. 
Jurnal Artefak: History and Education, Vol.5 No.1 April 2018 